\title{
Simple and Sensitive Spectrophotmetric Determination of Lamotrigine in Pure Form and in Dosage Forms
}

\author{
Rajendraprasad ${ }^{1 *}$, Basavaiah $K^{2}$, Vinay KB² and Ramesh $\mathbf{P J}^{2}$ \\ ${ }^{1}$ Department of Chemistry, J.S.S. College, Ooty Road, Mysore-570025, Karnataka, India \\ ${ }^{2}$ Department of Studies in Chemistry, Manasagangothri, University of Mysore, Mysore-560 006, India
}

\begin{abstract}
Two new simple, sensitive and cost-effective spectrophotometric methods for the determination of lamotrigine (LMT) in bulk drug and in tablets are described. The methods are based on the measurement of absorbance of LMT either in $0.1 \mathrm{M} \mathrm{H}_{2} \mathrm{SO}_{4}$ (method A) or in methanol (method B) at $225 \mathrm{~nm}$. Linearity was found to be in the ranges, 0.55.0 and 1.25-12.5 $\mathrm{mgmL}^{-1} \mathrm{LMT}$, for method $A$ and method $B$, respectively with apparent molar absorptivity values of $8.65 \times 10^{4}$ and $2.11 \times 10^{4} \mathrm{I} \mathrm{mol}^{-1} \mathrm{~cm}^{-1}$. The Sandell sensitivity values, limits of detection (LOD) and quantification (LOQ) values have also been reported for both the methods. The accuracy and precision of the methods were evaluated on intra-day and inter-day basis; the relative error (\%RE) and the relative standard deviation (RSD) were $<2.0 \%$. The proposed methods were applied to the determination of the examined drug in coated tablet and no interference from any common pharmaceutical additives and diluents was observed. Results of assay were validated statistically by parallel analysis and by recovery studies.
\end{abstract}

Keywords: Spectrophotometry; Determination; Lamotrigine; Pharmaceutical formulations

\section{Introduction}

Lamotrigine (LMT), [6-(2,3-dichlorophenyl)-1,2,4-triazine-3,5diamine], is an anticonvulsant drug and has been used as antiepileptic to treat epilepsy and bipolar disorder as monotherapy and as an adjunct with other antiepileptics for treatment of partial and generalized toxicchronic seizures. It is also used to treat neurological lesions and as a tranquilizer [1,2]. Its chemical structure is given in figure 1.

LMT is not official in any pharmacopoeia. Chromatographic techniques have been widely employed for the determination of LMT in body fluids. Published methods for the determination of LMT in biological samples include high-performance liquid chromatography (HPLC) [3-10], high-performance thin layer chromatography (HPTLC) [11] and gas-chromatography (GC) [12] and for assay in pharmaceuticals include planar chromatography [13], TLC and HPLC [14], HPLC and GC [15] and capillary electrophoresis [16,17] have been reported. Two immunoassay techniques $[18,19]$ have also been developed for determination of LMT in biological samples. Few methods have been reported for its determination in pharmaceuticals and include titrimetry [20] with acetous perchloric acid, in anhydrous acetic acid medium, UV- spectrophotometry [21] and visible spectrophotometry [22-25]. The uv-spectrophotometric method [21] was used for determination of LMT in tablets, where the tablet extract in $0.1 \mathrm{M} \mathrm{NaOH}$ was measured at $305 \mathrm{~nm}$. Youssef and Taha [14] have reported the application of visible spectrophotometry for the determination of LMT using chloranilic acid as a chromogen. The reported method is less sensitive with a linear range $10-200 \mu \mathrm{gmL}^{-1}$ and<smiles>Nc1nnc(-c2cccc(Cl)c2Cl)c(N)n1</smiles>

Figure 1: Chemical structure of LMT. the molar absorptivity of $1.28 \times 10^{3} \mathrm{~mol}^{-1} \mathrm{~cm}^{-1}$. Though the method is claimed to be selective, any $\mathrm{N}$-containing basic moiety would definitely interfere with the assay. The extraction spectrophotometric methods [22-25] are at the other hand involves tedious extraction steps and consumes longer time for the analysis.

Many of the other reported methods [13-17] are sensitive and selective but they are time consuming, require expensive instrumental setup, and some require preliminary sample treatment. Adsorptive stripping voltammetric method [26] is highly complicated and is reported to be less precise (RSD, $\sim 10 \%$ ). Considering these drawbacks, there was a need to develop more advantageous spectrophotometric method for its determination in bulk powder and commercial dosage forms.

The objective of this investigation is to develop new simple, fast, sensitive, selective, reliable and inexpensive UV Spectrophotometric methods for the determination of LMT in bulk drug and commercial pharmaceutical formulations. The methods are based on the measurement of absorbance of LMT solution in either $0.1 \mathrm{M} \mathrm{H}_{2} \mathrm{SO}_{4}$ or methanol at $225 \mathrm{~nm}$.

\section{Experimental}

\section{Apparatus}

The Spectrophotometric measurements were carried out using Shimadzu Pharmaspec 1700 UV/Visible spectrophotometer.

*Corresponding author: Rajendraprasad N, Department of Chemistry, J.S.S. College, Ooty Road, Mysore-570025, Karnataka, India, E-mail: prasadtnpur@yahoo.co.in

Received November 15, 2012; Accepted November 21, 2012; Published November 25, 2012

Citation: Rajendraprasad N, Basavaiah K, Vinay KB, Ramesh PJ (2012) Simple and Sensitive Spectrophotmetric Determination of Lamotrigine in Pure Form and in Dosage Forms. Pharmaceut Anal Acta 3: 188. doi:10.4172/2153-2435.1000188

Copyright: () 2012 Rajendraprasad N, et al. This is an open-access article distributed under the terms of the Creative Commons Attribution License, which permits unrestricted use, distribution, and reproduction in any medium, provided the original author and source are credited. 
Citation: Rajendraprasad N, Basavaiah K, Vinay KB, Ramesh PJ (2012) Simple and Sensitive Spectrophotmetric Determination of Lamotrigine in Pure Form and in Dosage Forms. Pharmaceut Anal Acta 3: 188. doi:10.4172/2153-2435.1000188

Page 2 of 5

\section{Chemicals and reagents}

All chemicals used were of analytical reagent grade.

Pure LMT (pharmaceutical grade, 99.88\%) sample was kindly provided by Cipla India Ltd, Mumbai, India, as a gift and used as received. Commercial dosage forms used: lamosyn 100 and lamosyn 25 (both from Sun Pharmaceuticals Ltd, Mumbai, India) and Lametec 50DT (Cipla India Ltd, Mumbai, India)-all tablets were purchased from local commercial sources.

\section{Standard solutions}

Sulphuric acid $(0.1 \mathrm{M})$ was prepared by successive dilutions of appropriate volume of concentrated acid (S.D. Fine Chem, Mumbai, India, sp. gr. 1.84) in water. Methanol AR (S.D. Fine Chem, Mumbai, India) was used as solvent in the present study.

\section{Standard drug solution}

Standard drug solutions of $10 \mu \mathrm{gmL}^{-1}$ in $0.1 \mathrm{M} \mathrm{H}_{2} \mathrm{SO}_{4}$ and $25 \mu \mathrm{gmL}^{-1}$ LMT in methanol were prepared separately and used for assay in method A and method B, respectively.

\section{Procedures}

\section{Recommended procedure and calibration curve}

Method A: Varying amounts of aliquots (0.5, 1.0, 2,0, 3.0, 4.0 and $5.0 \mathrm{~mL}$ ) of working standard solution corresponding to $0.5-5.0$ $\mu \mathrm{gmL}^{-1} \mathrm{LMT}$ were taken into a series of $10 \mathrm{~mL}$ volumetric flasks and volume was made upto mark with $0.1 \mathrm{M} \mathrm{H}_{2} \mathrm{SO}_{4}$. The absorbance of each solution was measured at $225 \mathrm{~nm} v s .0 .1 \mathrm{M} \mathrm{H}_{2} \mathrm{SO}_{4}$.

Method B: Into a series of $10 \mathrm{~mL}$ calibration flasks, aliquots of lamotrigine standard solution $\left(25 \mu \mathrm{gmL}^{-1}\right)$ equivalent to $1.25-12.5$ $\mu \mathrm{gmL}^{-1}$ LMT were accurately transferred and volume was made upto mark with methanol. The absorbance of each solution was measured at $225 \mathrm{~nm} v$ s. methanol.

In both the cases, calibration curves were plotted and the concentration of the unknown was read from the calibration graph or computed from the regression equation derived using Beer's law data.

\section{Procedure for tablets}

Method A: Weighed amount of tablet powder equivalent to $10 \mathrm{mg}$ of LMT was transferred into a $100 \mathrm{~mL}$ volumetric flask. The content was shaken well with about $50 \mathrm{~mL}$ of $0.1 \mathrm{M} \mathrm{H}_{2} \mathrm{SO}_{4}$ for $20 \mathrm{~min}$. The mixture was diluted to the mark with the same acid. It was filtered using Whatman No 42 filter paper. First $10 \mathrm{~mL}$ portion of the filtrate was discarded and a subsequent portion was diluted to get a working concentration of $10 \mu \mathrm{gmL}^{-1}$ and subjected to analysis following the procedure described earlier.

Method B: Tablet powder equivalent to $10 \mathrm{mg}$ of LMT was transferred into a $100 \mathrm{~mL}$ volumetric flask. The content was shaken well with about $50 \mathrm{~mL}$ of methanol for $20 \mathrm{~min}$ and diluted to the mark with the same solvent. It was filtered using Whatman No 42 filter paper. First $10 \mathrm{~mL}$ portion of the filtrate was discarded and subsequent portion was analyzed after dilution to $25 \mu \mathrm{gmL}^{-1} \mathrm{LMT}$ with methanol.

\section{Results and Discussion}

\section{Spectral characteristics}

The LMT was dissolved either in $0.1 \mathrm{M} \mathrm{H}_{2} \mathrm{SO}_{4}(\operatorname{method} \mathrm{A})$ or methanol (method B) and the absorbance measured at $225 \mathrm{~nm}$, and at this wavelength blank solution had insignificant absorbance as shown by the absorption spectra in figure 2 .

\section{Method validation}

Linearity, sensitivity, limits of detection and quantification: A linear correlation was found between absorbance at $\lambda_{\max }$ and concentration of LMT in the ranges given in table 1. The graphs are described by the regression equation:

$\mathrm{Y}=\mathrm{a}+\mathrm{bX}$ (Where $\mathrm{Y}=\mathrm{absorbance}$ of $1 \mathrm{~cm}$ layer of solution; $\mathrm{a}=$ intercept; $\mathrm{b}=$ slope and $\mathrm{X}=$ concentration in $\left.\mu \mathrm{gmL}^{-1}\right)$. Regression analysis of the Beer's law data using the method of least squares was made to evaluate the slope (b), intercept (a) and correlation coefficient (r) for each system and the values are presented in Table 1. A plot of $\log$ absorbance $v s$. $\log$ concentration, yielded straight lines with slope equal to 0.991 and 1.02 for method A and method B, respectively, further establishing the linear relation between the two variables. The optical characteristics such as Beer's law limits, molar absorptivity and Sandell sensitivity values [27] of all the three methods are also given in table 1. The limits of detection (LOD) and quantitation (LOQ) calculated according to $\mathrm{ICH}$ guidelines [28] using the formulae:

$\mathrm{LOD}=3.3 \mathrm{~S} / \mathrm{b}$ and $\mathrm{LOQ}=10 \mathrm{~S} / \mathrm{b}$, (where $\mathrm{S}$ is the standard deviation of blank absorbance values, and $b$ is the slope of the calibration plot) are also presented in table 1 . The high values of $\varepsilon$ and low values of

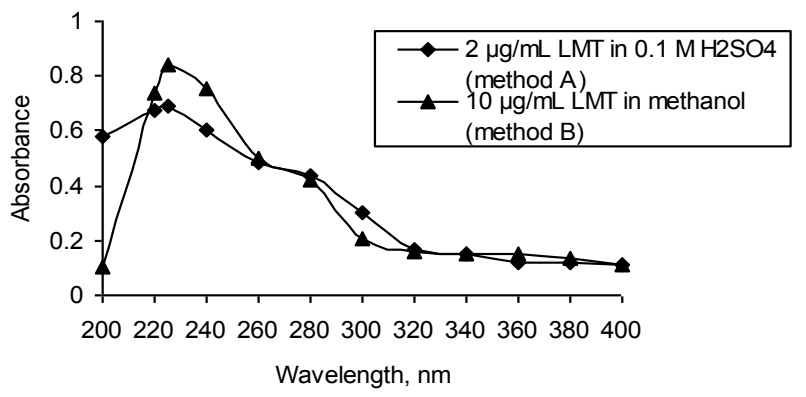

Figure 2: UV absorption spectra of LMT.

\begin{tabular}{|c|c|c|}
\hline Parameter & Method A & Method B \\
\hline$\lambda \max , \mathrm{nm}$ & 225 & 225 \\
\hline Linear range, $\mu \mathrm{gmL}^{-1}$ & $0.5-5.0$ & $1.25-12.5$ \\
\hline Molar absorptivity $(\varepsilon), \mathrm{L} \mathrm{mol}^{-1} \mathrm{~cm}^{-1}$ & $8.65 \times 10^{4}$ & $2.11 \times 10^{4}$ \\
\hline Sandell sensitivity ${ }^{\star}, \mu \mathrm{g} \mathrm{cm}^{-2}$ & 0.003 & 0.0121 \\
\hline Limit of detection (LOD), $\mu \mathrm{gmL}^{-1}$ & 0.01 & 0.03 \\
\hline Limit of quantification (LOQ), $\mu \mathrm{gmL}^{-1}$ & 0.02 & 0.09 \\
\hline \multicolumn{3}{|l|}{ Regression equation, $\mathrm{Y}^{* *}$} \\
\hline Intercept (a) & 0.0161 & -0.0094 \\
\hline Slope (b) & 0.3311 & 0.0849 \\
\hline Standard deviation of a $\left(\mathrm{S}_{\mathrm{a}}\right)$ & 0.0998 & 0.0998 \\
\hline Standard deviation of $b\left(S_{b}\right)$ & 0.032 & 0.0124 \\
\hline Variance $\left(\mathrm{Sa}^{2}\right)$ & 0.01 & 0.01 \\
\hline Regression coefficient ( $r$ ) & 0.9999 & 0.9999 \\
\hline
\end{tabular}

"Limit of determination as the weight in $\mu \mathrm{g}$ per $\mathrm{mL}$ of solution, which corresponds to an absorbance of $A=0.001$ measured in a cuvette of cross-sectional area $1 \mathrm{~cm}^{2}$ and $\mathrm{I}=1 \mathrm{~cm}$.

${ }^{*} Y=a+b X$, Where $Y$ is the absorbance, $X$ is concentration in $\mu \mathrm{gmL}^{-1}$, a is intercept $b$ is slope.

Table 1: Sensitivity and regression parameters. 
Citation: Rajendraprasad N, Basavaiah K, Vinay KB, Ramesh PJ (2012) Simple and Sensitive Spectrophotmetric Determination of Lamotrigine in Pure Form and in Dosage Forms. Pharmaceut Anal Acta 3: 188. doi:10.4172/2153-2435.1000188

Page 3 of 5

Sandell sensitivity and LOD indicate the high sensitivity of the proposed methods.

Precision and accuracy: The assays described under "general procedures" were repeated seven times within the day to determine the repeatability (intra-day precision) and five times on different days to determine the intermediate precision (inter-day precision) of the methods. These assays were performed for three levels of analyte. The results of this study are summarized in table 2 . The percentage relative standard deviation (\%RSD) values were $\leq 1.96 \%$ (intra-day) and $\leq$ $1.99 \%$ (inter-day) indicating high precision of the methods. Accuracy was evaluated as percentage relative error (RE) between the measured mean concentrations and taken concentrations for LMT. Bias \{bias $\%=[$ (Concentration found-known concentration $) \times 100 /$ known concentration] $\}$ was calculated at each concentration and these results are also presented in table 2 . Percent relative error (\%RE) values of $\leq$ $1.67 \%$ demonstrate the high accuracy of the proposed methods.

Selectivity: A systematic study was performed to determine the effect of matrix by analyzing the placebo blank and synthetic mixture containing LMT. A placebo blank of the composition: starch $(10 \mathrm{mg})$, acacia (15 mg), hydroxyl cellulose $(10 \mathrm{mg})$, sodium citrate $(10 \mathrm{mg})$, talc $(20 \mathrm{mg})$, magnesium stearate $(15 \mathrm{mg})$ and sodium alginate $(10 \mathrm{mg})$ was made and its solution was prepared as described under 'tablets', and then subjected to analysis. The absorbance of the placebo solution in each case was almost equal to the absorbance of the blank which revealed no interference. To assess the role of the inactive ingredients on the assay of LMT, a synthetic mixture was separately prepared by adding $10 \mathrm{mg}$ of LMT to the placebo mentioned above. The drug was extracted and solution prepared as described under the general procedure for tablets. The solutions after appropriate dilution were analyzed following the recommended procedures. The absorbance resulting from 3 and $8 \mu \mathrm{gmL}^{-1} \mathrm{LMT}$ solution in method A and method $\mathrm{B}$, respectively, had nearly the same as those obtained for pure LMT solutions of identical concentrations. This unequivocally demonstrated the non-interference of the inactive ingredients in the assay of LMT. Further, the slopes of the calibration plots prepared from the synthetic mixture solutions were about the same as those prepared from pure drug solutions.

Robustness and ruggedness: The robustness of the methods was evaluated by making small incremental changes in the concentration of $\mathrm{H}_{2} \mathrm{SO}_{4}$ in method A. The results obtained from the altered acid conditions were not different compared to the optimum conditions. Method ruggedness was demonstrated having the analysis done by four analysts, and also by a single analyst performing analysis on four different instruments in the same laboratory. Intermediate precision values (\%RSD) in both instances were in the range $0.88-1.65 \%$ indicating acceptable ruggedness. The results are presented in table 3.

Analysis of pharmaceutical formulations: The proposed methods were applied for the quantification of LMT in commercial tablets. The results were compared with these obtained using a published method [14]. The method consisted of the measurement of the absorbance of the charge-transfer complex of LMT with $p$-chloranilic acid in acetone at $519 \mathrm{~nm}$. Statistical analysis of the results did not detect any significant difference between the performance of the proposed methods and reference method with respect to accuracy and precision as revealed by the Student's t-value and variance ratio F-value [29]. The results of assay are given in table 4 .

Recovery study: To further assess the accuracy of the methods, recovery experiments were performed by applying the standardaddition technique. The recovery was assessed by determining the agreement between the measured standard concentration and added known concentration to the sample. The test was done by spiking the pre-analysed tablet powder with pure LMT at three different levels $(50$ 100 and $150 \%$ of the content present in the tablet powder (taken) and the total was found by the proposed methods. Each test was repeated

\begin{tabular}{|c|c|c|c|c|c|c|c|}
\hline \multirow[t]{2}{*}{ Method } & \multirow[t]{2}{*}{$\begin{array}{l}\text { LMT taken, } \\
\qquad \mathrm{g} \mathrm{mL}^{-1}\end{array}$} & \multicolumn{3}{|c|}{$\begin{array}{l}\text { Intra-day accuracy and precision } \\
\qquad(n=7)\end{array}$} & \multicolumn{3}{|c|}{$\begin{array}{l}\text { Inter-day accuracy and precision } \\
\qquad(\mathrm{n}=5)\end{array}$} \\
\hline & & $\begin{array}{c}\text { LMT } \\
\text { found } \pm C L \\
\mu g \mathrm{~mL}^{-1}\end{array}$ & $\%$ RE & \%RSD & $\begin{array}{l}\text { LMT found } \pm \mathrm{CL} \\
\qquad \mu \mathrm{g} \mathrm{mL}-1\end{array}$ & $\%$ RE & $\%$ RSD \\
\hline A & $\begin{array}{l}1.0 \\
3.0 \\
5.0\end{array}$ & $\begin{array}{l}0.99 \pm 0.04 \\
3.05 \pm 0.12 \\
4.98 \pm 0.11\end{array}$ & $\begin{array}{c}1.0 \\
1.67 \\
0.4\end{array}$ & $\begin{array}{l}1.52 \\
1.65 \\
0.89\end{array}$ & $\begin{array}{l}1.01 \pm 0.03 \\
3.03 \pm 0.07 \\
4.96 \pm 0.14\end{array}$ & $\begin{array}{l}1.0 \\
1.0 \\
0.8\end{array}$ & $\begin{array}{l}0.98 \\
0.86 \\
1.02\end{array}$ \\
\hline B & $\begin{array}{c}4.0 \\
8.0 \\
12.0\end{array}$ & $\begin{array}{c}4.05 \pm 0.19 \\
8.12 \pm 0.24 \\
12.02 \pm 0.46\end{array}$ & $\begin{array}{c}1.25 \\
1.5 \\
0.12\end{array}$ & $\begin{array}{l}1.96 \\
1.23 \\
1.56\end{array}$ & $\begin{array}{c}4.03 \pm 0.17 \\
7.98 \pm 0.32 \\
11.86 \pm 0.65\end{array}$ & $\begin{array}{l}0.75 \\
0.25 \\
1.17\end{array}$ & $\begin{array}{l}1.55 \\
1.46 \\
1.99\end{array}$ \\
\hline
\end{tabular}

\%RE. Percent relative error, \%RSD. relative standard deviation and CL. Confidence limits were calculated from: $C L= \pm t S / \sqrt{ }$. (The tabulated value of $t$ is 2.45 and 2.77 for six and four degrees of freedom respectively, at the $95 \%$ confidence level; $S=$ standard deviation and $n=$ number of measurements).

Table 2: Evaluation of intra-day and inter-day accuracy and precision.

\begin{tabular}{|c|c|c|c|c|}
\hline \multirow{3}{*}{ Method } & \multirow{3}{*}{$\begin{array}{l}\text { LMT taken, } \\
\mu \mathrm{g} \mathrm{mL}^{-1}\end{array}$} & Robustness & \multicolumn{2}{|c|}{ Ruggedness } \\
\hline & & Parameter altered ${ }^{*}$ & \multirow{2}{*}{$\begin{array}{l}\text { Inter-analysts, (\%RSD) } \\
\qquad(\mathrm{n}=4)\end{array}$} & \multirow{2}{*}{$\begin{array}{c}\text { Inter-instruments, } \\
(\% \mathrm{RSD}) \\
(\mathrm{n}=4)\end{array}$} \\
\hline & & $\begin{array}{c}\mathrm{H}_{2} \mathrm{SO}_{4} \text { concentration, } \\
(\% \mathrm{RSD})\end{array}$ & & \\
\hline$A$ & 6.0 & 1.56 & 0.88 & 1.65 \\
\hline $\mathrm{B}$ & 8.0 & - & 0.99 & 1.58 \\
\hline
\end{tabular}

In method $\mathrm{A}$, concentration of $\mathrm{H}_{2} \mathrm{SO}_{4}$ were $0.08,0.1$ and $0.12 \mathrm{M}$

Table 3: Method robustness and ruggedness expressed as intermediate precision (\% RSD). 
Citation: Rajendraprasad N, Basavaiah K, Vinay KB, Ramesh PJ (2012) Simple and Sensitive Spectrophotmetric Determination of Lamotrigine in Pure Form and in Dosage Forms. Pharmaceut Anal Acta 3: 188. doi:10.4172/2153-2435.1000188

Page 4 of 5

three times. In all the cases, the recovery percentage values ranged between 100.8 and $105.1 \%$ with relative standard deviation in the range $0.98-1.56 \%$. Closeness of the results to $100 \%$ showed the fairly good accuracy of the methods. The results are shown in table 5 .

\section{Conclusions}

Two UV-spectrophotometric methods for the determination of lamotrigine in bulk drug and in pharmaceutical dosage forms were developed and validated for accuracy, precision, linearity, robustness and ruggedness. The proposed methods have better linear dynamic ranges and sensitivity compared to the reported uv [21] and visible [14] spectrophotometric methods (Table 6). The methods have the advantages of simplicity without involving heating or extraction step and high sensitivity. No interference due to co-formulated substances was observed when applied to the determination in tablets. Hence,

\begin{tabular}{|c|c|c|c|c|}
\hline \multirow{3}{*}{$\begin{array}{l}\text { Tablet brand } \\
\text { name }\end{array}$} & \multirow{3}{*}{$\begin{array}{l}\text { Nominal amount, } \\
\text { (mg/tablet) }\end{array}$} & \multicolumn{3}{|c|}{ Found $^{*}$ (Percent of label claim $\pm S D$ ) } \\
\hline & & \multirow[t]{2}{*}{ Reference method } & \multicolumn{2}{|c|}{ Proposed methods } \\
\hline & & & Method A & Method B \\
\hline Lamosyn- $100^{\mathrm{a}}$ & 100 & $101.3 \pm 0.42$ & $\begin{array}{c}102.1 \pm 1.04 \\
t=1.73 \\
F=6.13\end{array}$ & $\begin{array}{c}100.8 \pm 0.86 \\
t=1.23 \\
F=4.19\end{array}$ \\
\hline Lamosyn-25a & 25 & $97.48 \pm 0.62$ & $\begin{array}{c}98.72 \pm 0.92 \\
t=2.54 \\
F=2.2\end{array}$ & $\begin{array}{c}96.85 \pm 1.48 \\
t=0.77 \\
F=5.70\end{array}$ \\
\hline Lametec-50 DT ${ }^{\mathrm{b}}$ & 50 & $103.5 \pm 0.72$ & $\begin{array}{c}104.1 \pm 1.46 \\
t=0.87 \\
F=4.11\end{array}$ & $\begin{array}{c}102.8 \pm 1.62 \\
t=0.95 \\
F=5.06\end{array}$ \\
\hline
\end{tabular}

"Mean value of 5 determinations.

(Tabulated $\mathrm{t}$-value at the $95 \%$ confidence level and for four degrees of freedom is 2.77 ).

(Tabulated F-value at the $95 \%$ confidence level and for four degrees of freedom is 6.39 ).

Marketed by : aSun pharmaceuticals.

${ }^{\mathrm{b}}$ Cipla India Ltd, Mumbai.

Table 4: Results of analysis of tablets by the proposed methods and statistical comparison of the results with the reference method.

\begin{tabular}{|c|c|c|c|c|c|c|c|c|}
\hline \multirow[b]{2}{*}{ Tablet studied } & \multicolumn{4}{|c|}{ Method A } & \multicolumn{4}{|c|}{ Method B } \\
\hline & LMT in tablet, $\boldsymbol{\mu} \mathbf{g} \mathbf{~ m L}^{-1}$ & $\begin{array}{c}\text { Pure LMT } \\
\text { added, } \boldsymbol{\mu g m L}^{-1}\end{array}$ & $\begin{array}{l}\text { Total found, } \\
\boldsymbol{\mu g} \mathbf{~ m L}^{-1}\end{array}$ & $\begin{array}{c}\text { Pure LMT } \\
\text { recovered } \\
\left.\text { (Percent } \pm \mathbf{S D}^{\star}\right)\end{array}$ & $\begin{array}{l}\text { LMT in tablet, } \\
\boldsymbol{\mu g m L}^{-1}\end{array}$ & $\begin{array}{c}\text { Pure LMT } \\
\text { added, } \boldsymbol{\mu g m L}^{-1}\end{array}$ & $\begin{array}{l}\text { Total found, } \\
\boldsymbol{\mu g m L}^{-1}\end{array}$ & $\begin{array}{l}\text { Pure LMT recovered } \\
\quad\left(\text { Percent } \pm \text { SD }^{*}\right)\end{array}$ \\
\hline Lamosyn-100 & $\begin{array}{l}2.04 \\
2.04 \\
2.04\end{array}$ & $\begin{array}{l}1.0 \\
2.0 \\
3.0\end{array}$ & $\begin{array}{l}3.077 \\
4.142 \\
5.097\end{array}$ & $\begin{array}{l}103.7 \pm 1.32 \\
105.1 \pm 1.08 \\
101.9 \pm 1.56\end{array}$ & $\begin{array}{l}4.03 \\
4.03 \\
4.03\end{array}$ & $\begin{array}{l}2.0 \\
4.0 \\
6.0\end{array}$ & $\begin{array}{l}6.062 \\
8.062 \\
10.18\end{array}$ & $\begin{array}{l}101.6 \pm 1.32 \\
100.8 \pm 0.98 \\
102.5 \pm 1.16\end{array}$ \\
\hline
\end{tabular}

"Mean value of three determinations.

Table 5: Results of recovery study via standard-addition method.

\begin{tabular}{|c|c|c|c|c|c|c|c|c|}
\hline S. No. & Reagent/s used & Methodology & $\begin{array}{c}\lambda_{\max } \\
(\mathrm{nm})\end{array}$ & $\begin{array}{l}\text { Linear range } \\
\left(\mu \mathrm{gmL}^{-1}\right)\end{array}$ & $\begin{array}{c}\mathrm{LOQ} \\
\left(\mu \mathrm{g} \mathrm{mL} \mathrm{mL}^{-1}\right)\end{array}$ & Reaction time & Remarks & Ref. \\
\hline 1. & $p$-Chloroanilic acid & $\begin{array}{c}\text { Pink coloured C-T } \\
\text { complex was measured. }\end{array}$ & 519 & $\begin{array}{c}10-200 \\
\left(€=1.28 \times 10^{3}\right. \\
\left.L \mathrm{~mol}^{-1} \mathrm{~cm}^{-1}\right)\end{array}$ & - & Instantaneous & \multirow[t]{2}{*}{ Less sensitive } & [14] \\
\hline 2. & $0.1 \mathrm{M} \mathrm{NaOH}$ & $\begin{array}{l}\text { LMT in } \mathrm{NaOH} \text { was } \\
\text { measured. }\end{array}$ & 305 & $2-50$ & - & - & & [21] \\
\hline \multirow{2}{*}{3} & a) BCG/Dichloromethane & Ion-pair extraction & 410 & $1.5-15$ & 1.3 & $5 \min$ & \multirow{2}{*}{$\begin{array}{l}\text { Tedious extraction procedure } \\
\text { involved and Less sensitive }\end{array}$} & \multirow{2}{*}[22]{} \\
\hline & b) Alcoholic $\mathrm{KOH}$ & Ion-pair breaking & 620 & $0.5-5.0$ & 0.59 & Instantaneous & & \\
\hline \multirow{3}{*}{4} & a) $\mathrm{BPB} / \mathrm{CHCl}_{3}$ & Ion-pair extraction & 420 & $2.5-25 \mu \mathrm{g} \mathrm{mL}^{-1}$ & 0.15 & $5 \min$ & \multirow{9}{*}{$\begin{array}{c}\text { Tedious extraction procedure } \\
\text { involved }\end{array}$} & \\
\hline & b) Ethanolic $\mathrm{H}_{2} \mathrm{SO}_{4}$ & \multirow{2}{*}{ lon-pair breaking } & 420 & $50-400 \mathrm{ng} \mathrm{mL}^{-1}$ & 0.003 & \multirow{2}{*}{ Instantaneous } & & \multirow{2}{*}{ [23] } \\
\hline & c) Ethanolic $\mathrm{KOH}$ & & 600 & $10-80 \mathrm{ng} \mathrm{mL}^{-1}$ & 0.0005 & & & \\
\hline \multirow{3}{*}{5} & a) BCP/dichloromethane & Ion-pair extraction & 410 & $2.0-20.0 \mu \mathrm{g} \mathrm{mL}^{-1}$ & 0.8 & $5 \min$ & & \multirow{3}{*}{ [24] } \\
\hline & b) Ethanol & \multirow{2}{*}{ lon-pair breaking } & 410 & $150-1500 \mathrm{ng} \mathrm{mL}^{-1}$ & 0.06 & \multirow{2}{*}{ Instantaneous } & & \\
\hline & c) Ethanolic $\mathrm{KOH}$ & & 600 & $50-600 \mathrm{ng} \mathrm{mL}^{-1}$ & 0.02 & & & \\
\hline \multirow{3}{*}{6} & a) Bromocresol green/ $\mathrm{CHCl}_{3}$ & \multirow{3}{*}{ Ion-pair extraction } & NA & $0.15-19.8 \mu \mathrm{g} \mathrm{mL}^{-1}$ & NA & NA & & \multirow{3}{*}{ [25] } \\
\hline & b) Bromocresol purple/ $\mathrm{CHCl}_{3}$ & & NA & $0.15-19.8 \mu \mathrm{g} \mathrm{mL}^{-1}$ & NA & NA & & \\
\hline & c) Chlorophenol red/ $\mathrm{CHCl}_{3}$ & & NA & $0.05-34.1 \mu \mathrm{g} \mathrm{mL} \mathrm{L}^{-1}$ & NA & NA & & \\
\hline
\end{tabular}


Citation: Rajendraprasad N, Basavaiah K, Vinay KB, Ramesh PJ (2012) Simple and Sensitive Spectrophotmetric Determination of Lamotrigine in Pure Form and in Dosage Forms. Pharmaceut Anal Acta 3: 188. doi:10.4172/2153-2435.1000188

Page 5 of 5

\begin{tabular}{|c|c|c|c|c|c|c|c|c|}
\hline \multirow{2}{*}{7} & a) $0.1 \mathrm{M} \mathrm{H}_{2} \mathrm{SO}_{4}$ & $\begin{array}{l}\mathrm{LMT} \text { in } 0.1 \mathrm{M} \mathrm{H}_{2} \mathrm{SO}_{4} \\
\text { was measured. }\end{array}$ & 225 & $\begin{array}{c}0.5-5.0 \\
\left(€=8.65 \times 10^{4}\right. \\
\left.L \mathrm{~mol}^{-1} \mathrm{~cm}^{-1}\right)\end{array}$ & 0.02 & - & \multirow{2}{*}{$\begin{array}{l}\text { Very simple, and wide linear } \\
\text { dynamic ranges. }\end{array}$} & \multirow{2}{*}{$\begin{array}{l}\text { Present } \\
\text { work. }\end{array}$} \\
\hline & b) Methanol & $\begin{array}{l}\text { LMT in methanol was } \\
\text { measured. }\end{array}$ & 225 & $\begin{array}{c}1.25-12.5 \\
\left(€=2.11 \times 10^{4}\right. \\
\left.L \mathrm{~mol}^{-1} \mathrm{~cm}^{-1}\right)\end{array}$ & 0.09 & - & & \\
\hline
\end{tabular}

NA. Not available

Table 6: Performance characteristic of the existing spectrophotometric methods and the proposed methods.

the proposed methods could be adopted for quality control in pharmaceutical industries.

\section{Aknowledgement}

Authors thank M/S. Cipla India Ltd, for gifting pure lamotrigine. Two of the authors (KBV and PJR) thanks the authorities of the University of Mysore, Mysore for permission and facilities. One of the authors (NRP) thanks the J.S.S. institute for finding platform to pursue research work.

\section{References}

1. Hardman JG, Limbird LE (2001) Goodman and Gilman's - The Pharmacological Basis of Therapeutics. (10thedn), McGraw Hill, New York, USA

2. Sweetman SC (2007) Martindale: The Complete Drug Reference (4thedn), Pharmaceutical Press, London.

3. Cociglio M, Alric R, Bouvier O (1991) Performance analysis of a reversedphase liquid chromatographic assay of lamotrigine in plasma using solventdemixing extraction. J. Chromatogr 572: 269-276.

4. Lensmeyer GL, Gidal BE, Wiebe DA (1997) Optimized high-performance liquid chromatographic method for determination of lamotrigine in serum with concomitant determination of phenytoin, carbamazepine, and carbamazepine epoxide. Ther Drug Monit 19: 292-300.

5. Angelis-Stoforidis P, Morgan DJ, O'Brien TJ, Vajda FJ (1999) Determination of lamotrigine in human plasma by high-performance liquid chromatography. $\mathrm{J}$ Chromatogr B Biomed Sci Appl 727: 113-118.

6. Croci D, Salmaggi A, de Grazia U, Bernardi G (2001) New high-performance liquid chromatographic method for plasma/serum analysis of lamotrigine. Ther Drug Monit 23: 665-668.

7. Castel-Branco MM, Almeida AM, Falcão AC, Macedo TA, Caramona MM, et al. (2001) Lamotrigine analysis in blood and brain by high-performance liquid chromatography. J Chromatogr B Biomed Sci Appl 755: 119-127.

8. Cheng CL, Chou $\mathrm{CH}$, Hu OY (2005) Determination of lamotrigine in smal volumes of plasma by high-performance liquid chromatography. J Chromatogr B Analyt Technol Biomed Life Sci 817: 199-206.

9. Matar KM, Nicholls PJ, Bawazir SA, al-Hassan MI, Tekle A (1998) A rapid liquid chromatographic method for the determination of lamotrigine in plasma. J Pharm Biomed Anal 17: 525-531.

10. Londero D, Lo Greco P (1997) New micromethod for the determination of lamotrigine in human plasma by high-performance liquid chromatography. $\mathrm{J}$ Chromatogr B Biomed Sci Appl 691: 139-144.

11. Patil KM, Bodhankar SL (2005) High-performance thin-layer chromatographic determination of lamotrigine in serum. J Chromatogr B Analyt Technol Biomed Life Sci 823: 152-157.

12. Hallbach J, Vogel H, Guder WG (1997) Determination of lamotrigine, carbamazepine and carbamazepine epoxide in human serum by gas chromatography mass spectrometry. Eur J Clin Chem Clin Biochem 35: 755759.

13. Dreassi E, Corbini G, Corti P, Ulivelli M, Rocchi R (1996) Quantitative analysis of lamotrigine in plasma and tablets by planar chromatography and comparison with liquid chromatography and UV spectrophotometry. J AOAC Intl 79: 12771280.

14. Youssef NF, Taha EA (2007) Development and validation of spectrophotometric, TLC and HPLC methods for the determination of lamotrigine in presence of its impurity. Chem Pharm Bull 55: 541-545.

15. Greiner-Sosanko E, Giannoutsos S, Lower DR, Virji MA, Krasowski MD (2007) Drug monitoring: simultaneous analysis of lamotrigine, oxcarbazepine, 10-hydroxycarbazepine, and zonisamide by HPLC-UV and a rapid GC method using a nitrogen-phosphorus detector for levetiracetam. J Chromatogr Sci 45 616-622.

16. Shihabi ZK, Oles KS (1996) Serum lamotrigine analysis by capillary electrophoresis. J Chromatogr B Biomed Appl 683: 119-123.

17. Theurillat R, Kuhn M, Thormann W (2002) Therapeutic drug monitoring of lamotrigine using capillary electrophoresis. Evaluation of assay performance and quality assurance over a 4-year period in the routine arena. $\mathrm{J}$ Chromatogr A 979: 353-368.

18. Biddlecombe RA, Dean KL, Smith CD, Jeal SC (1990) Validation of radioimmunoassay for the determination of human plasma concentrations of lamotrigine. J Pharm Biomed Anal 8: 691-694.

19. Sailstad JM, Findlay JW (1991) Immunofluorometric assay for lamotrigine (Lamictal) in human plasma. Ther Drug Monit 13: 433-442.

20. Rajendraprasad N, Basavaiah K, Vinay KB (2009) Determination of drug content of pharmaceuticals containing Lamotrigine by titrimetry in non-aqueous medium. Proc Indian Nat Sci Acad 75: 131-136.

21. Talekar RS, Dhake AS, Sonaje DB, Mourya VK (2000) Spectrophotometric determination of lamotrigine. Ind J Pharm Sci 62: 51-52.

22. Rajendraprasad N, Basavaiah K, Vinay KB (2010) Sensitive spectrophotometric determination of lamotrigine in bulk drug and pharmaceutical formulations using bromocresol green. Eclet Quim 35: 55-67.

23. Rajendraprasad N, Basavaiah K, Vinay KB (2010) Micro and nanogram determination of lamotrigine in pharmaceuticals by visible spectrophotometry using bromophenol blue. IJCT 17: 220-228.

24. Alizadeh N, Khakinahad R, Jabbari A (2008) Spectrophotometric determination of lamotrigine in pharmaceutical preparations and urine by charge-transfer complexation. Pharmazie 63: 791-795.

25. Vinay KB, Revanasiddappa HD, Rajendraprasad N (2009) Development and validation of spectrophotometric methods for the sensitive and selective determination of lamotrigine in pharmaceuticals using bromocresol purple. $J$ Food Drug Anal 17: 424-433.

26. Domínguez-Renedo O, Burgoa Calvo ME, Arcos-Martínez JM (2008) Determination of lamotrigine in pharmaceutical preparations by adsorptive stripping voltammetry using screen printed electrodes. Sensors 8: 4201-4212.

27. Zavis H, Ludvik D, Milan K, Ladislaw S, Frantisck V (1976) Handbook of Organic Reagents in Inorganic Analysis. The Series and Translation Editor University of Aberdem, Ellis Horwood Limited, Chichester, A Division of John Wiley \& Sons IC, New York, USA

28. International Conference on Hormonisation of Technical Requirements for Registration of Pharmaceuticals for Human Use (2005) $\mathrm{ICH}$ Harmonised Tripartite Guideline. Validation of Analytical Procedures: Text and Methodology Q2(R1). Complementary Guideline on Methodology, London.

29. Inczedy J, Lengyel T, Ure AM (1998) IUPAC Compendium of Analytica Nomenclature: Definitive Rules. Blackwell Science Inc., Boston, USA. 